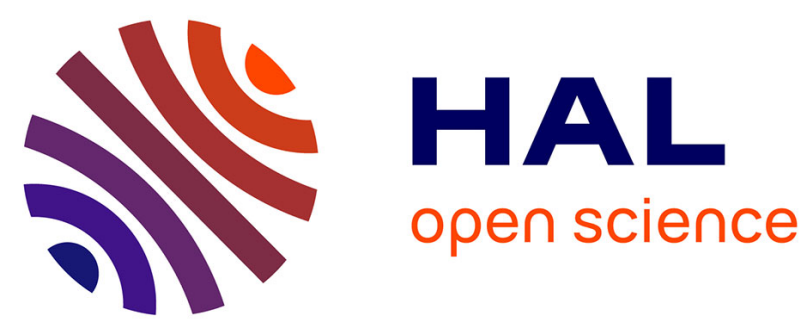

\title{
Polycyclic aromatic hydrocarbons (PAHs) in meat products and estimated PAH intake by children and general population in Estonia
}

Mari Reinik, Terje Tamme, Mati Roasto, Kadrin Juhkam, Toomas Tenno, Alida Kiis

\section{To cite this version:}

Mari Reinik, Terje Tamme, Mati Roasto, Kadrin Juhkam, Toomas Tenno, et al.. Polycyclic aromatic hydrocarbons (PAHs) in meat products and estimated PAH intake by children and general population in Estonia. Food Additives and Contaminants, 2007, 24 (04), pp.429-437. 10.1080/02652030601182862 . hal-00577539

\section{HAL Id: hal-00577539 \\ https://hal.science/hal-00577539}

Submitted on 17 Mar 2011

HAL is a multi-disciplinary open access archive for the deposit and dissemination of scientific research documents, whether they are published or not. The documents may come from teaching and research institutions in France or abroad, or from public or private research centers.
L'archive ouverte pluridisciplinaire HAL, est destinée au dépôt et à la diffusion de documents scientifiques de niveau recherche, publiés ou non, émanant des établissements d'enseignement et de recherche français ou étrangers, des laboratoires publics ou privés. 


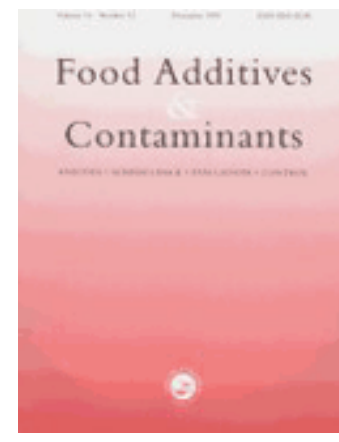

\section{Polycyclic aromatic hydrocarbons (PAHs) in meat products and estimated PAH intake by children and general population in Estonia}

\begin{tabular}{|c|c|}
\hline Journal: & Food Additives and Contaminants \\
\hline Manuscript ID: & TFAC-2006-218.R2 \\
\hline Manuscript Type: & Original Research Paper \\
\hline $\begin{array}{r}\text { Date Submitted by the } \\
\text { Author: }\end{array}$ & 06-Dec-2006 \\
\hline Complete List of Authors: & $\begin{array}{l}\text { Reinik, Mari; Health Protection Inspectorate, Tartu Laboratory } \\
\text { Tamme, Terje; Estonian University of Life Sciences, Department of } \\
\text { Food Hygiene and Control of Institute of Veterinary Medicine and } \\
\text { Animal Sciences } \\
\text { Roasto, Mati; Estonian University of Life Sciences, Department of } \\
\text { Food Hygiene and Control of Institute of Veterinary Medicine and } \\
\text { Animal Sciences } \\
\text { Juhkam, Kadrin; Estonian University of Life Sciences, Department } \\
\text { of Food Hygiene and Control of Institute of Veterinary Medicine and } \\
\text { Animal Sciences } \\
\text { Tenno, Toomas; University of Tartu, Institute of Physical Chemistry } \\
\text { Kiis, Alida; Estonian University of Life Sciences, Department of Food } \\
\text { Hygiene and Control of Institute of Veterinary Medicine and Animal } \\
\text { Sciences }\end{array}$ \\
\hline Methods/Techniques: & $\begin{array}{l}\text { Chromatography - GC/MS, Chromatography - HPLC, Exposure } \\
\text { assessment }\end{array}$ \\
\hline Additives/Contaminants: & PAH \\
\hline Food Types: & Meat, Smoked food \\
\hline
\end{tabular}




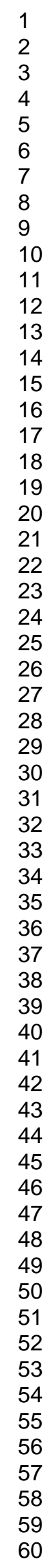

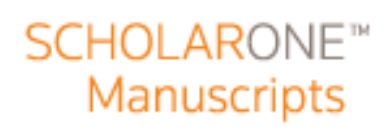

7

25

26

27

29

30

32

33

34

35

36

37

38

40

41

42

44

45

46

47

48

49

51

54

55

57

58

59

60

http://mc.manuscriptcentral.com/tfac Email: fac@tandf.co.uk 


\title{
Polycyclic aromatic hydrocarbons (PAHs) in meat products and estimated PAH intake by children and the general population in
} Estonia

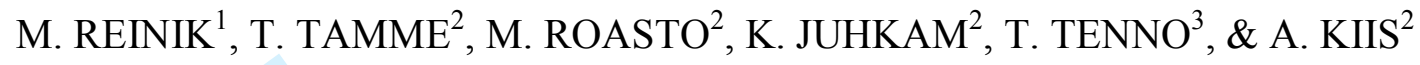 \\ ${ }^{1}$ Estonian Health Protection Inspectorate, Tartu Laboratory, PK 272, 50002 Tartu, \\ Estonia \\ ${ }^{2}$ Department of Food Hygiene and Control of Institute of Veterinary Medicine and \\ Animal Sciences, Estonian University of Life Sciences, Kreutzwaldi 58A, 51014 \\ Tartu, Estonia \\ ${ }^{3}$ Tartu University, Institute of Physical Chemistry, Jakobi 2, 51014 Tartu, Estonia
}

\begin{abstract}
The concentrations of benzo(a)pyrene and 11 other polycyclic aromatic hydrocarbons (PAHs) were analysed from 322 commercial cured meat products and 14 homegrilled meat samples as part of the Estonian food safety monitoring programme during 2001-2005. The maximum acceptable concentration of $5 \mu \mathrm{g} \mathrm{kg}^{-1}$ for benzo(a)pyrene was exceeded in $3.4 \%$ of samples. The highest PAH concentrations were detected in home-grilled pork samples. Using of disposable grilling unit resulted in 1.6 times higher PAH concentrations compared to the traditional wood-burning grill. The average intake of benzo(a)pyrene and sum of 12 PAHs from meat products was estimated for children (age 1-16 years) on the basis of individual food consumption questionnaire and for the general population based on the national food consumption
\end{abstract}


data. The highest total PAH concentrations detected were $16 \mu \mathrm{g} \mathrm{kg}^{-1}$ in smoked meat and ham, $19 \mu \mathrm{g} \mathrm{kg}^{-1}$ in smoked sausage and $6.5 \mu \mathrm{g} \mathrm{kg}^{-1}$ in smoked chicken samples. Since smoking and grilling are prevalent meat cooking methods in Estonia, the impact of meat products is assessed to be significant in overall PAH intake.

Keywords: polycyclic aromatic hydrocarbons, benzo(a)pyrene, meat products, intake 


\section{Introduction}

Polycyclic aromatic hydrocarbons (PAHs) include several potent carcinogenic compounds consisting of two or more fused aromatic rings. PAHs are formed during incomplete combustion processes or in high-temperature pyrolysis of coal, oil and other organic materials. The most important sources of PAHs have been identified as coke ovens in the production of aluminium, iron, and steel; heating in power plants and residences; cooking; motor vehicle traffic; environmental tobacco smoke; and the incineration of waste material (WHO 1998). Over 100 PAHs have been identified in the environment as pollutants occuring as complex mixtures (Mottier et al. 2000).

Many of PAHs have been demonstrated to be carcinogenic for experimental animals and they are also supposed to have a significant impact on the disease burden caused by various cancers in human population (Phillips 1999). PAHs highlighted to be genotoxic and carcinogenic by the Scientific Committee on Food (SCF) are the following: benz(a)anthracene, benzo(b)fluoranthene, benzo(j)fluoranthene, benzo(k)fluoranthene, benzo(g,h,i)perylene, benzo(a)pyrene, chrysene, cyclopenta(c,d)pyrene, dibenz(a,h)anthracene, dibenzo(a,e)pyrene, dibenzo(a,h)pyrene, dibenzo(a,i)pyrene, dibenzo(a,l)pyrene, indeno(1,2,3-cd)pyrene, 5-methylchrysene (European Commission 2005a). Joint Expert Committee on Food Additives (JECFA) has added 16th analyte to the list - 7H-benzo-(c)fluorene (JECFA 2005). European Commission has required further investigation of the levels of benzo(a)pyrene and other PAHs, in particular those highlighted to be carcinogenic by SCF, in food (European Commission 2005a, Wenzl et al. 2006). The International Agency of Research on Cancer (IARC) has categorized 15 PAHs, including benzo(a)pyrene, benz(a)anthrazene, benzo(b)fluoranthene, benzo(j)fluoranthene, 
benzo(k)fluoranthene, dibenz(a,h)anthracene, dibenzo(a,e)pyrene, dibenzo(a,i)pyrene, dibenzo(a,1)pyrene dibenzo(a,1)pyrene, indeno(1,2,3-cd)pyrene and 5-methylchrysene, as reasonably anticipated to be human carcinogens (IARC 1973, 1983, 1987). In mammalian cells PAHs undergo metabolic activation to diol epoxides that bind covalently to cellular macromolecules, including DNA, thereby causing errors in DNA replication and mutations that initiate the carcinogenic process (Janoszka et al. 2004).

Diet is the primary source of human exposure to PAHs contributing to more than $90 \%$ of total exposure to PAHs (WHO 1998, SCF 2002). PAHs may be present as contaminants in various food items and beverages including drinking water (Chen 2004, King et al. 2004), vegetables, fruits, cereals, oils (Dennis et al.1991, Moret and Conte 2000, Moret and Conte 2002, Rojo Camargo and Toledo 2003, Tao et al. 2006, Voutsa and Samara 1998), fish (Šimko 1991, Lodovici et al. 1995, Moret and Conte 2000, Yurchenko and Mölder 2005, Karl and Leinemann 1996, Stołyhwo and Sikorski 2005) and meat (Kazerouni et al. 2001, Elhassaneen 2004, Šimko 2002, Mottier 2000, Janoszka 2004). The possible sources of PAHs in food are environmental contamination from the atmosphere, soil or water, contamination from packaging materials and thermal treatment which is used for the preparation and manufacturing of food (Guillen 1994). PAHs are lipophilic and have very low aqueous solubility so they accumulate in lipid tissue of plants and animals. The levels of PAHs found in unprocessed foods reflect the background contamination which originates from long distance airborne transportation of contaminated particles and natural emissions. 
Food processing procedures, such as smoking, drying and cooking, are generally supposed to be the major sources of PAH contamination of food. Formation of PAHs in meat products is affected by several factors: the methods used for preparation of food (grilling, frying, roasting etc.), temperature and time of cooking, distance from the heat source and drainage of fat (SCF 2002, Kazerouni et al. 2001). Several mechanisms of formation of PAHs have been proposed, such as melted fat that undergoes pyrolysis when dripping onto the heat source and pyrolysis of the meat due to the high temperature (Lijinsky 1991). Because PAH formation occurs on or near the surface of meats, food cooked without being exposed to smoke does not show significant levels of PAH. The PAH concentrations in smoked food depend on several variables in the smoking process, including the type of smoke generator and wood, combustion temperature and degree of smoking (Moret et al. 1997). Lowering the temperature of smoke formation to $300-400{ }^{\circ} \mathrm{C}$ combined with the use of filters, the PAH content of smoke can be decreased by about 90\% (Sikorski 2005).

Benzo(a)pyrene $(\mathrm{BaP})$ is the most widely known and studied of the PAHs due to its importance as one of the most potent animal carcinogenic $\mathrm{PAH}$, its relatively easy analysis and presence in wide variety of food items. BaP seems to be a good marker for other PAHs in food items, the correlation coefficient between the total PAH and the $\mathrm{BaP}$ concentration has been detected to be 0.87 and between the carcinogenic PAHs and $\mathrm{BaP} 0.98$ (Kazerouni et al. 2001). Maximum acceptable concentration of 5 $\mu \mathrm{g} \mathrm{kg}{ }^{-1}$ has been established for $\mathrm{BaP}$ in smoked meats and smoked meat products (European Commission 2005b). 
Several methods for analysis have been used for the determination of PAHs in food. PAHs have been extracted from homogenized food samples using various techniques such as liquid-liquid extraction (Rojo Camargo and Toledo 2003) or supercritical fluid extraction (Järvenpää et al. 1996, Lage Yusty and Daviña 2005). Solid phase extraction (Nazarkina et al. 2001) and gel permeation chromatography (Yurchenko and Mölder 2005) have been used for sample cleanup. The determination of PAHs in food has been carried out by various analytical methods, including thin layer chromatography (Kazerouni et al. 2001, Moret and Conte 2000), high performance liquid chromatography (Chen et al. 1996, Chiu et al. 1997, Rojo Camargo and Toledo 2003, de Boer and Law 2003), gas chromatography with mass-selective detector (Mottier et al. 2000, Yurchenko and Mölder 2005, Jira 2004) or flame ionization detector (Moret and Conte 2000).

Intake of PAHs has been estimated in some European countries: in Austria, Italy, The Netherlands and UK, furthermore the estimated $\mathrm{BaP}$ intake is available for Germany, Sweden and USA (SCF 2002). According to several studies the major dietary contributors are cereals, oils and vegetables although PAH levels in cereals are often low (Dennis et al. 1983, de Vos et al.1990, Tao et al. 2006). Grilled or barbequed meat caused a significant proportion $(21 \%)$ of the average total daily $\mathrm{BaP}$ intake in USA according to the data obtained by Kazerouni et al. (2001).

Various food items and products in Estonia have been analysed for $\mathrm{BaP}$ content starting from year 1999 and for PAH content from 2003 in the framework of the Estonian food safety monitoring programme, initiated in 1998 (Reinik et al. 2001). The aim of the present study was to determine the levels of PAHs in commercial meat 
products and grilled meat prepared by traditional Estonian habits. Furthermore, the aim here was to estimate the human exposure to PAHs and $\mathrm{BaP}$ through various meat products. As grilling, smoking and barbequing of meat are widely used in Estonia, the assessment of dietary risks connected with the intake of PAHs is essential.

\begin{abstract}
Materials and methods
Meat samples

Altogether 322 samples from 34 Estonian meat manufacturers were analyzed in $2001-2005$ for the BaP content. Samples, from which 94\% constituted smoked and grilled meat products, were collected from the main retail outlets of Tartu, the second largest town in Estonia. Samples were divided into 9 product groups (Table II). In addition to $\mathrm{BaP}$, concentrations of $11 \mathrm{PAHs}$, included in the European Commission list (European Commission 2005a), were analysed from 22 industrial and 14 homegrilled meat products in 2005 .
\end{abstract}

Various types of grilling equipment are used for home-grilling. In present study two commonly used grilling methods were used: traditional wood burning grill and small disposable charcoal grill unit. In the traditional wood-burning grill the distance between burning coals and meat is approximately $20 \mathrm{~cm}$ and the temperature at the surface of the meat is between $180-240{ }^{\circ} \mathrm{C}$. In recent years disposable charcoal grills have gained popularity for their convenience and shorter preparation time. Compared to traditional grilling the heat source is much closer to the grilled product in these disposable grills. 14 samples of meat products were grilled using both methods and analyzed for the content of 12 PAHs. 
Analysis of PAHS

Analyses of the PAHs in meat samples were carried out at Tartu Laboratory of Estonian Health Protection Inspectorate. The gas chromatographic method with massselective detector (GC/MS) was used to determine the following PAHs: benz(a)anthracene, sum of benzo(b)-, benzo(j)- and benzo(k)fluoranthene, benzo(g,h,i)perylene, benzo(a)pyrene, chrysene, dibenz(a,h)anthracene, dibenzo(a,e)pyrene, dibenzo(a,1)pyrene, indeno(1,2,3-cd)pyrene and 5methylchrysene. High performance liquid chromatography (HPLC) with fluorescence detection was used for samples in which only benzo(a)pyrene content was measured.

For sample preparation the method described by Ojaveer and Tanner (1996) with some modifications was used. The sample was homogenized and hydrolyzed in concentrated hydrochloric acid overnight. Dichloromethane/hexane solution 25:75 was added. The solution was filtered through the layer of $\mathrm{Na}_{2} \mathrm{SO}_{4}$ and $\mathrm{NaHCO}_{3}$ 1:1. The eluate was evaporated to dryness, ethyl acetate/cyclohexane 50:50 solution was added. Portion of the extract was injected into a gel chromatograph. The fraction containing PAHs was collected and evaporated to dryness. The residue was dissolved in methanol.

For benzo(a)pyrene analysis an Hewlett Packard 1100 HPLC equipment with Agilent 1100 fluorescence detector was used. The limit of determination was $0,3 \mu \mathrm{g} \mathrm{kg}^{-1}$ and recovery was $80 \%$. A Hewlett Packard Model 6890 gas chromatograph equipped with mass selective detector and chromatographic column HP-5 (30m x 0.25 mm i.d. silica capillary column with film thickness of $0.25 \mu \mathrm{m}$ ) was used for the analysis of PAHs. The temperature was programmed from 80 to $300{ }^{\circ} \mathrm{C}$. Positive-ion chemical 
ionization mass spectrometry was performed with ammonia reagent gas. The method performance parameters are given in Table I.

Both methods are accredited by Estonian Accreditation Centre. This laboratory has successfully participated in international proficiency tests using both methods of analysis. A reference material, smoked fish paste containing 16 PAHs (prepared by Estonian Institute of Chemical Physics and Biolophysics), was analysed in each series of analyses, the results for HPLC and GC/MS analysis of benzo(a)pyrene are coincident in accepted range.

[Insert Table I about here]

\section{Method for intake estimation}

To obtain data about the consumption of cured meat products by children in Estonia a questionnaire developed by the scientists of the Food Hygiene and Control Department of Estonian University of Life Sciences was used. Questionnaires were distributed to schools, kindergartens and family doctor centres and asked to fill in by the children's parents. The main aim was to estimate the daily consumption of meat products by children. Data on the number and age of children in the family, consumption of meat products per child, preference for domestic and imported products and attitude towards food additives were included in the questionnaire. The data from 346 children were received in 2000 - 2003. For the statistical analysis of data the responses were grouped in five groups by age of the children. According to registered data the maximum and average amounts of consumed meat products in grams in various age groups were calculated. 
Food consumption data from Estonian Board of Statistics were used for the estimation of average intake of PAHs and $\mathrm{BaP}$ in the general population in Estonia. Furthermore, an estimation was made for $\mathrm{PAH}$ and $\mathrm{BaP}$ intake through theoretical consumption of $100 \mathrm{~g}$ of each meat product per day. The national food consumption data were collected in $2001-2004$.

\section{Results and discussion}

BaP in commercial meat products

During the years 2001-2005 the range and average concentrations of BaP in 322 samples from various industrial and commercially available meat products were determined (Table II). BaP contents in analyzed meat products were at range of $<0.3$ (below the determination limit) and $31.2 \mu \mathrm{g} \mathrm{kg}^{-1}$. In $64 \%$ of the analyzed samples BaP concentrations remained below the limit of determination $\left(<0,3 \mu \mathrm{g} \mathrm{kg}^{-1}\right)$. The maximum acceptable concentration of $5 \mu \mathrm{g} \mathrm{kg}^{-1}$ for BaP in smoked meat products (European Commission 2005b) was exceeded in 11 samples. High PAH concentration containing products were home-made ham, smoked meat, smoked chicken and smoked sausages with concentrations of $30.6,31.2,15.0$ and $20.0 \mu \mathrm{g} \mathrm{kg}^{-1}$, respectively.

[Insert Table II about here]

In one earlier study concentrations of $\mathrm{BaP}$ have been found in the range of 0.03-100 $\mu \mathrm{g} \mathrm{kg}^{-1}$ in smoked meat products (Šimko 2002). The highest concentrations were detected in smoked sausages and smoked ham. In cooked meat products in Poland 0.11-3.93 $\mu \mathrm{g} \mathrm{kg}^{-1}$ of BaP have been detected (Janoszka et al. 2004). 


\section{PAHs in commercial smoked meat products}

22 samples of meat products were analyzed for the concentrations of 12 PAHs in 2005 (Table III). Eleven of those, except benzo(g,h,i)perylene, are categorized by IARC as probable or possible carcinogens (IARC 1973, 1983, 1987).

[Insert Table III about here]

Benzo(a)anthracene was detected in 15 samples, $\mathrm{BaP}$ in 13 samples. Benzo(a)anthracene and chrysene were found in highest concentrations. 5methylchrysene, dibenzo(a,h)anthracene, dibenzo(a,l)pyrene, dibenzo(a,e)pyrene concentrations remained below the determination limit in all samples. PAHs were not found in 4 samples. There are several factors influencing the final PAH content in the products in smoking and grilling process: type of wood and smoke generator, smoke temperature, duration of smoking or grilling, availability of oxygen and oven dimensions. As most of the cooked sausages undergo only a slight smoking process, $\mathrm{BaP}$ and $\mathrm{PAH}$ concentrations close to or under the determination limits were observed.

Our results are consistent with the study by Phillips (1999) where the concentration range of total PAHs in smoked meat was between 2.6 and $29.8 \mu \mathrm{g} \mathrm{kg}^{-1}$, and highest concentration of carcinogenic PAHs was $16.0 \mu \mathrm{g} \mathrm{kg}^{-1}$. Reports of previous works (Šimko, 2002) indicate that $\mathrm{BaP}$ concentrations are between $1 \%$ and $20 \%$ of the total carcinogenic PAHs. According to our results BaP comprises in average $6.1 \%$ of the total sum of PAHs in commercial smoked meat products. 


\section{PAHs in home-made grilled meat products}

The contents of PAHs in grilled products are shown in Table IV. Using of disposable grill resulted in higher (maximum 1.6 times) concentrations of PAHs compared to traditional grilling.

\section{[Insert Table IV about here]}

Total amounts of 12 PAHs was higher in grilled pork than in grilled chicken or sausages. The difference occurs probably due to variation in fat content. When fatty meat is grilled, more fat drops onto the coals and due to the high temperature, PAHs are formed. In consequence, smoke carries the PAHs onto the surface of meat products. Lower concentrations of PAHs in sausages can be explained by shorter grilling time.

Benzo(a)pyrene, benzo(a)anthracene, sum of benzo(b),(k),(j)fluorenes, chrysene and benzo(g,h,i)perylene were detected in all samples. The highest concentrations were determined for chrysene, sum of benzo(b),(k),(j)fluorene and benzo(a)anthracene, maximum values being $6.2,5.1$ and $3.0 \mu \mathrm{g} \mathrm{kg}^{-1}$, respectively. The results in table IV indicate a certain relation between the amount of benzo(a)pyrene and total amount of PAHs. According to our results $\mathrm{BaP}$ comprises in general $6.3 \%$ of the total sum of the PAHs in home-grilled meat products.

Home-prepared meat products, especially those which were prepared using a disposable grill, contained higher concentrations of $\mathrm{BaP}$ and $\mathrm{PAHs}$ compared to commercial products. The mean concentration of $\mathrm{BaP}$ in industrial and disposablegrill meat was $0.7 \mu \mathrm{g} \mathrm{kg}^{-1}$ and $1.0 \mu \mathrm{g} \mathrm{kg}^{-1}$, respectively. The average levels of PAHs 
in home-grilled meat were higher compared to industrial smoked products, mean contents being correspondingly $12.5 \mu \mathrm{g} \mathrm{kg}^{-1}$ and $7.5 \mu \mathrm{g} \mathrm{kg}^{-1}$.

Elhassaneen (2004) determined 11 PAHs in charcoal-broiled beefburgers. The range of PAHs was between 0.31-14.95 $\mu \mathrm{g} \mathrm{kg} \mathrm{kg}^{-1}$ and most frequently pyrene and benzo(a)pyrene were detected. The range of BaP concentration was $0.99-4.8 \mu \mathrm{g} \mathrm{kg}^{-1}$. Contents of 16 PAHs in seven different barbequed meat sausages were determined in a Swiss study. The highest concentrations were found for phenanthrene and naphtalene, BaP contents were between "not detected" and $2.81 \mu \mathrm{g} \mathrm{kg}^{-1}$ (Mottier et al. 2000).

The highest concentrations of PAHs reported in meat have been detected in food cooked over open flames. For example, in barbecued meat, the total PAHs were found to be present at levels up to $164 \mu \mathrm{g} \mathrm{kg}^{-1}$; with $\mathrm{BaP}$ being present at levels as high as $30 \mu \mathrm{g} \mathrm{kg}^{-1}$ (Panalaks 1976). The results for the total sum of PAHs are difficult to compare between the studies published earlier by other authors as there is variation in analyzed compounds and several non-carcinogenic PAHs have been included in earlier works.

\section{Intake of BaP and PAHs by children from the consumption of meat products}

The questionnaire concerning the daily consumption of meat products children's parents were asked to complete during one observation week. Data from 346 children at the age of 1 to 16 years were obtained (Reinik et al. 2005). In the PAH and BaP intake estimation an individual approach was applied: using the mean concentrations of BaP (Table II) and PAHs detected in meat products (Table III and IV) and taking 
[Insert Tables V-VI about here]

The mean $\mathrm{BaP}$ intake by children was found to be $14 \mathrm{ng}$ per day, maximum reaching to $140 \mathrm{ng}$ per day. Intake per kg of body weight (bw) is higher in younger age groups (1-9 years), maximum intake is more than 10 -fold compared to the average value of $0.46 \mathrm{ng}$ per day per $\mathrm{kg}$ of $\mathrm{bw}$. The average intake of PAHs from meat products was found to be $192 \mathrm{ng}$ per day (Table VI), whereas maximum intake was estimated to be up to $1575 \mathrm{ng}$ per day. BaP comprises $7.3 \%$ of total $\mathrm{PAH}$ intake. Both for $\mathrm{BaP}$ and PAH the highest intake is obtained from smoked meat products followed by cooked sausages and grilled products.

Dietary intake of $\mathrm{BaP}$ by schoolchildren and toddlers estimated in a UK survey COT (SCF 2002) was in the range of 1.4-3.8 $\mathrm{ng} \mathrm{kg}^{-1}$ bw per day. Similarly to our work the youngest age groups were found to have the highest exposure for both $\mathrm{BaP}$ and $\mathrm{PAH}$ per kg of bw, about 2.4-fold higher intake than for adults (SCF 2002).

Intake of BaP and total PAHs by Estonian population from the consumption of meat products

Dietary intake of food contaminants depends on both the nutritional habits of the examined population group and the concentrations of contaminants in food. Food consumption data from the Board of Statistics were used in the calculation of average 
intake for the general population. Data include the size of the population and average amounts of monthly consumed meat products in Estonia in 2001-2004.

The lowest concentrations of $\mathrm{BaP}$ were detected in cooked sausages and beef hamburgers, $0.15 \mu \mathrm{g} \mathrm{kg}^{-1}$ as a mean value. However, cooked sausages are the most frequently used meat product in general population with the average consumption of $35 \mathrm{~g}$ per day. The mean intake of $\mathrm{BaP}$ from consuming cooked sausages was estimated to be $5.3 \mathrm{ng}$ per day in our study. The highest concentrations of $\mathrm{BaP}$ were determined in smoked and grilled meat products. From before-mentioned product groups smoked sausages give the highest intake of BaP; 11 ng per day. The average consumption of grilled, smoked and other cured meat products is $65 \mathrm{~g}$ per day in general Estonian population (Table VII) which generates BaP intake of 29 ng per day (0.45 $\mathrm{ng} \mathrm{kg}^{-1}$ bw per day). As food consumption database indicates only average consumption, the real intake values for persons who eat high quantities of meat products frequently can be much higher.

[Insert Table VII about here]

According to mean concentrations of PAHs found in present study and taking into account average daily consumption and the theoretical consumption of $100 \mathrm{~g}$ of meat product, average daily PAH intake was estimated. Highest concentrations of PAHs were detected in grilled meat, concentration of $16 \mu \mathrm{g} \mathrm{kg}^{-1}$. Consuming $26 \mathrm{~g}$ of smoked and grilled meat products per day as average in Estonia, causes a $234 \mathrm{ng}$ daily PAH intake (3.6 $\mathrm{ng} \mathrm{kg}^{-1}$ bw per day).

As different methods have been used for the estimation of intake of food contaminants and extensive variation of diets, results obtained in earlier studies differ 
to the large extent. In USA and in some European countries the estimated BaP intake from food is reported to be between 0.1-1.6 $\mu \mathrm{g}$ per day (Guillen and Sopelana 2003), according to surveys conducted in six EU countries the mean or national-averaged intake of $\mathrm{BaP}$ for an adult person was estimated to be between 0.05 and $0.29 \mu \mathrm{g}$ per day (SCF 2002) and the total intake of 19 PAHs was estimated to be $8.8 \mu \mathrm{g}$ per day in Finland (SCOOP report 2004). Large variation in estimated intake values is probably due to the food groups and items considered, differences in analytical methods and to statistical analysis of concentration values below the detection and determination limits. The estimated contribution of meat products to the overall intake of PAHs also differs between countries from very low for UK to $21 \%$ in USA and $27 \%$ in France resulting in the second contributing food group after bread and cereals (SCF 2002, SCOOP report 2004).

As smoking and grilling are prevalent meat preparation methods in Estonia, the impact of meat products is assumed to be significant in the overall $\mathrm{PAH}$ intake. The mean intake values obtained in this study were lower compared to the estimates by other countries, however the results showed that for high consumers intake may be significant and exceed average value up to 10 times.

\section{Conclusions}

The content of benzo(a)pyrene in 322 meat products was determined by an HPLC method. BaP contents in meat products were in the range of $<0.3$ and $31.2 \mu \mathrm{g} \mathrm{kg}^{-1}$, with a mean concentration of $0.8 \mu \mathrm{g} \mathrm{kg}^{-1}$. The maximum acceptable concentration of $5 \mu \mathrm{g} \mathrm{kg}^{-1}$ for BaP in smoked meat products was exceeded in 11 samples, mainly home-made ham, smoked meat and smoked chicken. Concentrations of 12 PAHs 
were determined in 22 commercial smoked and 14 home-grilled meat products. For smoked products the highest PAH concentrations were detected to be $19 \mu \mathrm{g} \mathrm{kg}^{-1}$, whereas the average concentration was $7.5 \mu \mathrm{g} \mathrm{kg}^{-1}$.

The intake of $\mathrm{BaP}$ and PAHs by Estonian children from meat products was estimated on the basis of the data obtained from the individual food consumption questionnaires. The mean $\mathrm{BaP}$ intake was found to be $14 \mathrm{ng}$ per day, maximum intake being more than 10 times higher. The average intake of PAHs by children from meat products was found to be $192 \mathrm{ng}$ per day, while maximum intake values were estimated to be up to $1575 \mathrm{ng}$ per day.

The mean intake by the general population from the consumption of meat products was found to be $29 \mathrm{ng}$ of $\mathrm{BaP}$ per day and $346 \mathrm{ng}$ of total PAH per day. For consumption of $100 \mathrm{~g}$ of smoked or grilled meat products per day the mean daily intake was estimated to be $87 \mathrm{ng}$ for $\mathrm{BaP}$ and $942 \mathrm{ng}$ for PAHs. The PAH intake from the consumption of meat products per kg of body weight is highest among children in a age group of 1-9 years; the mean daily intake exceeding by 1.5 times, and the maximum by 10 -fold the average intake of the whole population $\left(5.3 \mathrm{ng} \mathrm{kg}^{-1}\right.$ bw per day).

Considering the toxicity of PAHs and high consumption of grilled and smoked meat products in Estonia, the data reported on the levels of carcinogenic PAHs in food and information on daily intake by children and the whole population is clearly significant. 


\section{References}

Chen BH, Wang CY, Chiu CP. 1996. Evaluation of analysis of polycyclic aromatic hydrocarbons in meat products by liquid chromatography. Journal of Agricultural Food Chemistry, 44:2244-2251.

Chen H. 2004. Determination of polycyclic aromatic hydrocarbons in water by solidphase microextraction and liquid chromatography. Analytical Science, 20:1383-1388.

Chiu CP, Lin YS, Chen BH. 1997. Comparison of GC/MS and HPLC for overcoming matrix interferences in the analysis of PAHs in smoked food. Chromatographia, 44:497-504.

de Boer J, Law R.J. 2003. Developments in the use of chromatographic techniques in marine laboratories for the determination of halogenated contaminants and polycyclic aromatic hydrocarbons. Journal of Chromatography A, 1000:223-251.

Dennis MJ, Massey RC, McWeeny DJ, Knowles ME, Watson D. 1983. Analysis of polycyclic aromatic hydrocarbons in the UK total diet. Food and Chemical Toxicology, 21:569-574.

Dennis MJ, Massey RC, Gripps G, Venn J, Howarth N, Lee G. 1991. Factors affecting the polycyclic aromatic hydrocarbon content of cereals, fats and other food products. Food Additives and Contaminants, 8:517-530. 
Elhassaneen YA. 2004. The effects of charcoal-broiled meat consumption on antioxidant defense system of erythrocytes and antioxidant vitamins in plasma. Nutrition Research, 24: 435-446.

European Commission. 2005a. Commission Recommendation 2005/108/EC of 4 February 2005 on the further investigation into the levels of polycyclic aromatic hydrocarbons in certain foods. Official Journal of the European Union L34: 43-45.

European Commission. 2005b. Commission Regulation No. 208/2005 of 4 February 2005 amending Regulation (EC) No 466/2001 as regards polycyclic aromatic hydrocarbons. Official Journal of the European Union L34: 3-5.

Guillen MD. 1994. Polycyclic aromatic compounds: extraction and determination in food. Food Additives and Contaminants, 11:669-684.

Guillén MD, Sopelana P. 2003. Polycyclic Aromatic Hydrocarbons in Diverse Foods. In: D’Mello JPF, editor. Food Safety. Contaminants and Toxins. Edinburgh, UK: CABI. p. 175.

IARC. 1973. Some polycyclic aromatic hydrocarbons and heterocyclic compounds. In: IARC monographs on the evaluation of carcinogenic risk of chemicals to humans. Vol.3. Lyon, France: IARC, 271 pp. 
IARC 1987. Overall evaluations of carcinogenicity. In: IARC monographs on the evaluation of carcinogenic risk of chemicals to humans. Supplement 7. Lyon, France: IARC, $440 \mathrm{pp}$.

Janoszka B, Warzecha L, Blaszczyk U, Bodzek D. 2004. Organic Compounds Formed in Thermally Treated High-protein Food. Part I: Polycyclic Aromatic Hydrocarbons. Acta Chromatographica, 14:115-128.

JECFA/64/SC. 2005. Summary and Conclusions of the Joint FAO/WHO Expert Committee on Food Additives. Sixty-Fourth meeting. Rome, 8-17 February 2005.

Järvenpää E, Huopalahti R, Tapanainen P. 1996. Use of supercritical fluid extractionhigh performance liquid chromatography in the determination of polynuclear aromatic hydrocarbons from smoked and broiled fish. Journal of Liquid Chromatography, RT19:1473-1482.

Jira W. 2004. A GC/MS method for the determination of carcinogenic polycyclic aromatic hydrocarbons (PAH) in smoked meat products and liquid smokes. European Food Research and Technology, 218:208-212. 
Karl H, Leinemann M. 1996. Determination of polycyclic aromatic hydrocarbons in smoked fishery products from different smoking kilns. Zeitschrift für LebensmittelUntersuchung unf-Forschung, 202:458-464.

\author{
Kazerouni N, Sinha R., Hsu C-H, Greenberg A, Rothman N. 2001. Analysis of 200 \\ food items for benzo(a)pyrene and estimation of its intake in an epidemiologic study. \\ Food and Chemical Toxicology, 39:423-436.
}

King AG, Readman JW, Zhou JL. 2004. Determination of polycyclic aromatic hydrocarbons in water by soli-phase microextraction-gas chromatography-mass spectrometry. Analytica Chimica. Acta, 523:259-267.

Lage Yusty MA, Cortizo Daviña JL. 2005. Supercritical fluid extraction and highperformance liquid chromatography-fluorescence detection method for polycyclic aromatic hydrocarbons investigation in vegetable oil. Food Control, 16:59-64.

SCOOP report - Collection of occurrence data on polycyclic aromatic hydrocarbons in food. 2004. Report of experts participating in Task 3.2.12. DG Health and Consumer Protection.

http://ec.europa.eu/food/food/chemicalsafety/contaminants/scoop_3-2-

$\underline{12 \text { final report pah en.pdf }}$

Lijinsky W. 1991. The formation and occurrence of polynuclear aromatic hydrocarbons associated with food. Mutation Research, 259:252-261. 
Lodovici M, Dolara P, Casalini, C, Clapellano S, Testolin G. 1995. Polycyclic aromatic hydrocarbon contamination in the Italian diet. Food Additives and Contaminants, 12:703-713.

Moret S, Piani B, Bortolomeazzi R, Conte LS. 1997. HPLC determination of polyaromatic hyrdocarbons in olive oils. Zeitschrift für Lebensmittel-Untersuchung und-Forshung A, 205:116-120.

Moret S, Conte LS. 2000. Polycyclic aromatic hydrocarbons in edible fats and oils: occurrence and analytical methods. Journal of Chromatography A, 882:245-253.

Moret S, Conte LS. 2002. A rapid method for polycyclic aromatic hydrocarbon determination in vegetable oil. Journal of Separation Science, 25:96-100.

Mottier P, Parisod V, Turesky R.J. 2000. Quantitative Determination of Polycyclic Aromatic Hydrocarbons in Barbecued Meat Sausages by Gas Chromatography Coupled to Mass Spectometry. Journal of Agricultural Food Chemistry, 48:11601166.

Nazarkina SG, Bulanova AV, Larionov OG. 2001. Solid-phase extraction of polycyclic aromatic hydrocarbons using polymer sorbents. Zhurnal analiticheskoi Khimii, 56:394-397. 
Ojaveer H, Tanner R. 1996. Levels of polycyclic aromatic hydrocarbons in eelpout, zoarces viviparous, in Estonian marine waters. Proceedings of the Estonian Academy of Sciences Ecology, 6:136-143.

Panalaks, T. 1976. Determination and identification of polycyclic aromatic hydrocarbons in smoked and charcoal-broiled food products by high pressure liquid chromatography. Journal of Environment Science and Health B, 11:299-315.

Phillips DH. 1999. Polycyclic aromatic hydrocarbons in the diet. Mutation Research, 443:139-147.

Reinik M, Ilmoja K, Minjajev M. 2001. Estonian National Monitoring programme of Food Additives 2000. Estonia: Rebellis. 96 p.

Reinik M, Tamme T, Roasto M, Juhkam K, Jurtšenko S, Tenno T, Kiis A. 2005. Nitrites, nitrates and $N$-nitrosoamines in Estonian cured meat products: Intake by Estonian children and adolescents. Food Additives and Contaminants, 22:1098-1105.

Rojo Camargo MC, Toledo MCF. 2003. Polycyclic aromatic hydrocarbons in Brazilian vegetables and fruits. Food Control, 14:49-53.

SCF/CS/CNTM/PAH/29 ADDI Final 4 December 2002. Polycyclic aromatic hydrocarbons - occurence in foods, dietary exposure and health effects. Background document to the opinion of the Scientific Committee on Food on the risks to human 
health of polycyclic aromatic hydrocarbons in food. Brussels http://europa.eu.int/comm/food/fs/sc/scf/index_en.html

Sikorski E. 2005. The effect of processing on the nutritional value and toxicity of foods. In: Dabrowski M, Sikorski ZE, editors. Toxins in food. USA: CRC press p.285.

Šimko P. 2002. Determination of polycyclic aromatic hydrocarbons in smoked meat products and smoke flavouring food additives. Journal of Chromatography B, 770: 318.

Šimko P. 1991. Changes of benzo(a)pyrene in smoked fish during storage. Food Chemistry, 40:293-300.

Stołyhwo A, Sikorski ZE. 2005. Polycyclic aromatic hydrocarbons in smoked fish a critical review. Food Chemistry, 91:303-311.

Tao S, Jiao XC, Chen SH, Liu WX., Coveney Jr RM., Zhu LZ, Luo YM.. 2006. Accumulation and distribution of polycyclic aromatic hydrocarbons in rice (Oryza sativa). Environmental Pollution, 140:406-415.

de Vos RH, van Dokkum W, Schouten A, de Jomg-Berkhout P. 1990. Polycyclic aromatic hydrocarbons in Dutch total diet samples 1984-1986. Food Chemistry and Toxicology, 28:263-268. 
Voutsa D, Samara C. 1998. Dietary intake of trace elements and polycyclic aromatic hydrocarbons via vegetables grown in an industrial Greek area. The Science of the Total Environment 218:203-216.

Wenzl T, Simon R, Kleiner J, Anklam E. 2006. Analytical methods for polycyclic aromatic hydrocarbons (PAHs) in food and the environment needed for new legislation in the European Union. Trends in Analytical Chemistry 25:716-725.

WHO.1998. Environmental Health Criteria 202. Selected Non-heterocyclic PAHs. Available from: URL: http://www.inchem.org/documents/ehc/ehc/ehc202.htm.

Yurchenko S, Mölder U. 2005. The determination of polycyclic aromatic hydrocarbons in smoked fish by gas chromatography mass spectrometry with positive ion chemical ionization. Journal of Food Composition and Analysis 18:857-869. 
Table I GC/MS method performance characteristics

\begin{tabular}{lcccc}
\hline PAHs & $\begin{array}{c}\text { Retention time } \\
(\mathrm{min})\end{array}$ & $\begin{array}{c}\text { Detection limit } \\
\left(\mu \mathrm{g} \mathrm{kg}^{-1}\right)\end{array}$ & $\begin{array}{c}\text { Determination } \\
\text { limit } \\
\left(\mu \mathrm{g} \mathrm{kg}^{-1}\right)\end{array}$ & $\begin{array}{c}\text { Recovery } \\
\%\end{array}$ \\
\hline Benzo(a)anthracene & 12.25 & 0.2 & 0.7 & 101 \\
¿ Benzo(b),(k),(j) & 17.09 & 0.3 & 0.9 & 97 \\
fluoranthene & 25.73 & 0.2 & 0.5 & 87 \\
Benzo(g,h,i)perylene & 18.75 & 0.1 & 0.3 & 90 \\
Benzo(a)pyrene & 12.40 & 0.2 & 0.7 & 97 \\
Chrysene & 24.83 & 0.2 & 0.7 & 99 \\
Dibenzo(a,h)anthracene & 32.57 & 0.2 & 0.5 & 99 \\
Dibenzo(a,e)pyrene & 30.74 & 0.2 & 0.5 & 85 \\
Dibenzo(a,l)pyrene & 24.57 & 0.3 & 1.0 & 92 \\
Indeno(1,2,3)pyrene & 14.21 & 0.2 & 0.7 & 98 \\
5-methylchrysene & & & & \\
\hline
\end{tabular}


Table IIBenzo(a)pyrene concentrations $\left(\mu \mathrm{g} \mathrm{kg}^{-1}\right)$ in 322 commercial meat products in Estonia 2001-2005.

\begin{tabular}{lcccc}
\hline Product group & No. of samples & $\begin{array}{c}\text { Concentration } \\
\text { range } \\
\left(\mu \mathrm{g} \mathrm{kg}^{-1}\right)\end{array}$ & $\begin{array}{c}\text { Median } \\
\text { concentration } \\
\left(\mu \mathrm{g} \mathrm{kg}^{-1}\right)\end{array}$ & $\begin{array}{c}\text { Average } \\
\text { concentration } \\
\left(\mu \mathrm{g} \mathrm{kg}^{-1}\right)\end{array}$ \\
\hline Smoked sausage & 115 & $<0.3-20$ & $<0.3$ & 1.1 \\
Ham & 116 & $<0.3-30.6$ & $<0.3$ & 0.8 \\
Smoked meat & 20 & $<0.3-31.2$ & 0.5 & 0.7 \\
Smoked chicken & 29 & $<0.3-15.0$ & 0.3 & 1.3 \\
Grilled chicken & 6 & $<0.3-1.0$ & 0.6 & 0.5 \\
Grilled sausage & 10 & $<0.3-1.2$ & 0.7 & 0.6 \\
Grilled meat & 6 & $0.7-1.8$ & 1.0 & 1.1 \\
Cooked sausage & 16 & $<0.3-1.0$ & $<0.3$ & 0.15 \\
Others & 4 & $<0.3$ & $<0.3$ & \\
& & & & \\
Total no. of samples & 322 & & & \\
\hline
\end{tabular}


Table III PAH concentrations $\left(\mu \mathrm{g} \mathrm{kg}^{-1}\right)$ in 22 commercial smoked meat products in Estonia 2005.

\begin{tabular}{|c|c|c|c|c|c|c|}
\hline \multirow[t]{2}{*}{ PAH } & \multicolumn{2}{|c|}{$\begin{array}{c}\text { Ham } \\
n=6\end{array}$} & \multicolumn{2}{|c|}{$\begin{array}{c}\text { Smoked sausage } \\
n=13\end{array}$} & \multicolumn{2}{|c|}{$\begin{array}{c}\text { Smoked chicken } \\
\mathrm{n}=3\end{array}$} \\
\hline & range & mean & range & mean & range & mean \\
\hline Benzo(a)anthracene & $<0.7-3.2$ & 1.6 & $<0.7-5.6$ & 1.6 & $1.0-2.2$ & 1.7 \\
\hline$\Sigma$ Benzo(b),(k),(j) fluoranthene & $<0.9-3.8$ & 1.3 & $<0.9-2.4$ & 0.9 & $<0.9-1.2$ & 0.7 \\
\hline $\operatorname{Benzo}(\mathrm{g}, \mathrm{h}, \mathrm{i})$ perylene & $<0.5-0.5$ & 0.3 & $<0.5-0.7$ & 0.4 & $<0.5$ & 0.25 \\
\hline Benzo(a)pyrene & $<0.3-0.5$ & 0.4 & $<0.3-1.3$ & 0.4 & $<0.3-0.8$ & 0.4 \\
\hline Chrysene & $<0.7-5.5$ & 2.6 & $<0.7-7.0$ & 2.0 & $<0.7-1.3$ & 0.9 \\
\hline Dibenzo(a,h)anthracene & $<0.7$ & & $<0.7$ & & $<0.7$ & \\
\hline Dibenzo(a,e)pyrene & $<0.5$ & & $<0.5$ & & $<0.5$ & \\
\hline Dibenzo(a,l)pyrene & $<0.5$ & & $<0.5$ & & $<0.5$ & \\
\hline Indeno(1,2,3)pyrene & $<1.0-1.1$ & 0.6 & $<1.0-2.4$ & 0.8 & $<1.0$ & 0.5 \\
\hline 5-methylchrysene & $<0.7$ & & $<0.7$ & & $<0.7$ & \\
\hline$\Sigma 12$ all PAHs & & 8.0 & & 7.3 & & 5.7 \\
\hline
\end{tabular}

Concentrations below determination limit (LOQ) were counted as $\mathrm{LOQ} / 2$ to calculate mean levels of PAHs. 
Table IV PAH concentrations $\left(\mu \mathrm{g} \mathrm{kg}^{-1}\right)$ in 14 Estonian home-grilled meat products.

\begin{tabular}{|c|c|c|c|c|c|c|c|c|c|c|c|c|}
\hline \multirow{3}{*}{ PAHs } & \multicolumn{4}{|c|}{ Grilled pork } & \multicolumn{4}{|c|}{ Grilled sausage } & \multicolumn{4}{|c|}{ Grilled chicken } \\
\hline & \multicolumn{2}{|c|}{$\begin{array}{c}\text { Wood burning } \\
\text { grill } \\
\mathrm{n}=3\end{array}$} & \multicolumn{2}{|c|}{$\begin{array}{c}\text { Disposable } \\
\text { charcoal grill } \\
n=3\end{array}$} & \multicolumn{2}{|c|}{$\begin{array}{l}\text { Wood burning } \\
\text { grill } \\
n=2\end{array}$} & \multicolumn{2}{|c|}{$\begin{array}{c}\text { Disposable } \\
\text { charcoal grill } \\
\mathrm{n}=2\end{array}$} & \multicolumn{2}{|c|}{$\begin{array}{l}\text { Wood burning } \\
\text { grill } \\
n=2\end{array}$} & \multicolumn{2}{|c|}{$\begin{array}{c}\text { Disposable } \\
\text { charcoal grill } \\
n=2\end{array}$} \\
\hline & range & mean & range & mean & range & mean & range & mean & range & mean & range & mean \\
\hline Benzo(a)anthracene & $1.6-2.5$ & 1.9 & 3.0 & 3.0 & $1.4-2.1$ & 1.8 & $1.0-1.7$ & 1.4 & $0.7-1.2$ & 1.0 & $1.5-1.7$ & 1.6 \\
\hline $\begin{array}{l}\sum \text { Benzo(b),(k),(j)- } \\
\text { fluoranthene }\end{array}$ & $1.7-3.8$ & 3.0 & $4.3-5.1$ & 4.6 & $2.6-2.7$ & 2.6 & $2.7-3.5$ & 3.1 & $2.2-2.6$ & 2.4 & $3.0-3.6$ & 3.3 \\
\hline $\operatorname{Benzo}(\mathrm{g}, \mathrm{h}, \mathrm{i})$ perylene & $0.5-1.5$ & 1.1 & $1.8-2.3$ & 2.1 & $1.3-1.4$ & 1.4 & $1.4-1.5$ & 1.4 & $1.2-1.4$ & 1.3 & $1.5-1.8$ & 1.7 \\
\hline Benzo(a)pyrene & $0.7-1.0$ & 0.8 & $1.0-1.8$ & 1.4 & $0.6-0.8$ & 0.7 & 0.5 & 0.5 & $0.3-0.5$ & 0.4 & $0.8-1.0$ & 0.9 \\
\hline Chrysene & $2.4-6.2$ & 3.7 & $4.7-6.2$ & 5.6 & $1.5-2.3$ & 1.9 & $1.5-3.5$ & 2.5 & $0.9-1.6$ & 1.3 & $2.2-3.1$ & 2.7 \\
\hline $\begin{array}{l}\text { Dibenzo(a,h)- } \\
\text { anthracene }\end{array}$ & $<0.7$ & & $<0.7$ & & $<0.7$ & & $<0.7$ & & $<0.7$ & & $<0.7$ & \\
\hline Dibenzo(a,e)pyrene & $<0.5$ & & $<0.5$ & & $<0.5$ & & $<0.5$ & & $<0.5$ & & $<0.5$ & \\
\hline Dibenzo(a,l)pyrene & $<0.5$ & & $<0.5$ & & $<0.5$ & & $<0.5$ & & $<0.5$ & & $<0.5$ & \\
\hline $\begin{array}{l}\text { Indeno( }(1,2,3)- \\
\text { pyrene }\end{array}$ & $0.5-1.7$ & 0.9 & $1.7-2.0$ & 1.9 & 0.5 & 0.5 & 0.5 & 0.5 & $0.5-1.5$ & 1.0 & $0.5-1.8$ & 1.2 \\
\hline 5-methylchrysene & $<0.7$ & & $0.4-0.7$ & 0.6 & $<0.7$ & & 0.4 & 0.4 & $<0.7$ & & $0.4-0.7$ & 0.6 \\
\hline$\Sigma$ 12all PAHs & & 13 & & 20 & & 10 & & 11 & & 8.6 & & 13 \\
\hline
\end{tabular}

Concentrations below determination limit (LOQ) were counted as LOQ/2 to calculate mean levels of PAHs. 
Table V. Estimated daily intake of benzo(a)pyrene (ng per day and $\mathrm{ng} \mathrm{kg}^{-1}$ body weight per day) from the consumption of meat products by Estonian children.

\begin{tabular}{|c|c|c|c|c|c|c|c|c|c|c|}
\hline \multirow{3}{*}{ Age } & \multicolumn{8}{|c|}{ Daily intake of BaP (ng per day) } & \multirow{2}{*}{\multicolumn{2}{|c|}{$\begin{array}{c}\text { Daily intake of } \mathrm{BaP} \\
\left(\mathrm{ng} \mathrm{kg}^{-1} \text { bw per }\right. \\
\text { day })\end{array}$}} \\
\hline & \multicolumn{2}{|c|}{$\begin{array}{l}\text { Cooked } \\
\text { sausage }\end{array}$} & \multicolumn{2}{|c|}{$\begin{array}{c}\text { Smoked sausage } \\
\text { and ham }\end{array}$} & \multicolumn{2}{|c|}{$\begin{array}{l}\text { Grilled meat } \\
\text { products }\end{array}$} & \multicolumn{2}{|c|}{ Total } & & \\
\hline & Mean & Max & Mean & Max & Mean & Max & Mean & Max & Mean & Max \\
\hline $1-3$ & 2.7 & 7.7 & 2.4 & 37 & 1.2 & 21 & 6.3 & 66 & 0.47 & 4.7 \\
\hline $4-6$ & 4.8 & 13 & 4.3 & 37 & 1.9 & 19 & 11 & 69 & 0.55 & 3.5 \\
\hline $7-9$ & 4.8 & 17 & 6.2 & 86 & 2.2 & 37 & 13 & 140 & 0.47 & 5.0 \\
\hline $10-12$ & 4.2 & 20 & 8.2 & 76 & 2.7 & 37 & 15 & 133 & 0.40 & 3.5 \\
\hline $13-16$ & 6.8 & 20 & 13.3 & 53 & 5.1 & 18 & 25 & 91 & 0.39 & 1.4 \\
\hline Mean & 4.7 & & 6.9 & & 2.6 & & 14 & & 0.46 & \\
\hline
\end{tabular}


Table VI. Estimated daily intake of all PAHs (ng per day and $\mathrm{ng} \mathrm{kg}^{-1}$ body weight per day) from the consumption of meat products by Estonian children.

\begin{tabular}{|c|c|c|c|c|c|c|c|c|c|c|}
\hline \multirow{3}{*}{ Age } & \multicolumn{8}{|c|}{ Daily intake of PAH (ng per day) } & \multirow{2}{*}{\multicolumn{2}{|c|}{$\begin{array}{c}\text { Daily intake of } \\
\text { PAH } \\
\text { (ng kg-1 bw per } \\
\text { day) }\end{array}$}} \\
\hline & \multicolumn{2}{|c|}{$\begin{array}{l}\text { Cooked } \\
\text { sausage }\end{array}$} & \multicolumn{2}{|c|}{$\begin{array}{c}\text { Smoked sausage } \\
\text { and ham }\end{array}$} & \multicolumn{2}{|c|}{$\begin{array}{l}\text { Grilled meat } \\
\text { products }\end{array}$} & \multicolumn{2}{|c|}{ Total } & & \\
\hline & Mean & Max & Mean & Max & Mean & $\operatorname{Max}$ & Mean & $\operatorname{Max}$ & Mean & Max \\
\hline $1-3$ & 58 & 118 & 18 & 278 & 17.5 & 325 & $\begin{array}{l}94 \\
\end{array}$ & 721 & 7.0 & 53 \\
\hline $4-6$ & 102 & 275 & 32 & 278 & 30 & 300 & 164 & 853 & 8.2 & 43 \\
\hline 7-9 & 102 & 355 & 47 & 645 & 34 & 575 & 183 & 1575 & 6.5 & 56 \\
\hline $10-12$ & 90 & 426 & 62 & 570 & 43 & 575 & 195 & 1575 & 5.1 & 41 \\
\hline $13-16$ & 144 & 426 & 98 & 398 & 80 & 288 & 322 & 1112 & 5.0 & 17 \\
\hline Mean & 99 & & 51 & & 41 & & 192 & & 6.4 & \\
\hline
\end{tabular}


Table VII. Mean daily intake of benzo(a)pyrene and PAHs from the consumption of meat products in general population in Estonia calculated on the basis of the food consumption survey from the National Board of Statistics and the theoretical consumption of $100 \mathrm{~g}$ of each product per day.

\begin{tabular}{|c|c|c|c|c|c|c|c|}
\hline \multirow[b]{2}{*}{ Product group } & \multirow{2}{*}{$\begin{array}{c}\text { Average } \\
\text { consumption } \\
\text { (g per day) }\end{array}$} & \multirow{2}{*}{$\begin{array}{c}\text { Mean } \\
\text { BaP } \\
\text { content } \\
\left(\mu \mathrm{g} \mathrm{kg}^{-1}\right)\end{array}$} & \multirow{2}{*}{$\begin{array}{c}\text { Mean } \\
\Sigma 12 \text { PAHs } \\
\text { content } \\
\left(\mu \mathrm{g} \mathrm{kg}^{-1}\right)\end{array}$} & \multicolumn{2}{|c|}{$\begin{array}{c}\text { Mean BaP intake } \\
\text { (ng per day) }\end{array}$} & \multicolumn{2}{|c|}{$\begin{array}{l}\text { Mean total PAH intake } \\
\text { (ng per day) }\end{array}$} \\
\hline & & & & $\begin{array}{c}\text { At average } \\
\text { daily } \\
\text { consumption }\end{array}$ & $\begin{array}{l}\text { Through daily } \\
\text { consumption } \\
\text { of } 100 \mathrm{~g}\end{array}$ & $\begin{array}{c}\text { At average } \\
\text { daily } \\
\text { consumption }\end{array}$ & $\begin{array}{l}\text { Through daily } \\
\text { consumption } \\
\text { of } 100 \mathrm{~g}\end{array}$ \\
\hline Cooked sausage & 35 & 0.15 & 3.2 & 5.3 & 15 & 112 & 320 \\
\hline Smoked sausage & 10 & 1.1 & 7.3 & 11 & 110 & 75 & 730 \\
\hline Ham & 2.0 & 0.8 & 8.0 & 1.6 & 80 & 16 & 800 \\
\hline Smoked meat & 6.7 & 0.7 & 8.0 & 4.7 & 70 & 54 & 800 \\
\hline Smoked chicken & 1.0 & 1.3 & 5.7 & 1.3 & 130 & 5.7 & 570 \\
\hline Grilled chicken & 1.7 & 0.5 & 11 & 0.85 & 50 & 18 & 1100 \\
\hline Grilled sausage & 2.0 & 0.6 & 10 & 1.2 & 60 & 21 & 1000 \\
\hline Grilled meat & 2.7 & 1.1 & 16 & 3.0 & 110 & 44 & 1600 \\
\hline Others & 2.9 & 0.15 & - & 0.45 & 15 & - & - \\
\hline Total & 64 & & & 29 & & 346 & \\
\hline
\end{tabular}

